\title{
The Internet - Privacy and rights relating to personality
}

\author{
Alfonso-Luis Calvo Caravaca \\ Professor of Private International Law \\ Carlos III University, Madrid \\ Member of the UNIDROIT Governing Council \\ ORCID ID: 0000-0003-2236-4641
}

DOI: https://doi.org/10.20318/cdt.2020.5233
The course titled "The Internet - Privacy and rights relating to personality" was delivered in 2015 at the Hague Academy of International Law by JaVier Carrascosa, Professor of Private International Law at the University of Murcia, Spain, and published by the Academy in the volume Recueil des cours de l'Academie de droit international, The Hague, 2016, vol. 378, Leiden / Boston, Brill Nijhoff, pp. 261-486).

This is an unorthodox course for different reasons. In the first place, it focuses on a social reality that needs legal regulation: the violation of personality rights on the Internet. It is not, therefore, a course that merely studies legal norms: on the contrary, it explores the social phenomena related to rights relating to personality on the Internet first, and then and only then, does it review with the lens of a specialist in private international Law the legal rules governing them. Consequently, it should be noted that this course springs from a very solid double legal dogmatic base: an in-depth knowledge of the rights of personality and full mastery of the fundamental structures of the Internet. Another reason why the course may be defined heterodox is that it analyzes private international law from an economic point of view. To the author, the best solutions are those that involve lower costs for the parties and for society in general.

The text begins with a journey through the reality of the Internet - that new, flexible, ubiquitous, mobile, unstable and immediate continent. Then, Prof. Carrascosa deals with the different proposals that have been suggested for the regulation of the issue and advocates a clear option: private international law -a legal sector that is over 1,000 years old-has always proven able to readily adapt to social changes. In other word s, private international law has managed to acclimatize to the multiple fluctuations of social reality. For this re- ason, classical private international law can still provide adequate solutions to the issue at hand: new international grounds of jurisdiction and new connecting factors are being created in order to protect personality rights on the Internet. A classic yet sophisticated private international law is born in the 21st century to face this issue.

The course dwells then on the birth, growth and expansion -from the ancient Greeks to the $21^{\text {st }}$ century- of a legal category that is as attractive as it is volatile: personality rights, that is, a set of personal rights protected by international conventions and national Constitutions. Nevertheless, in these legal instruments the most difficult issue -i.e. the determination of international jurisdiction and the Law applicable to personality rights in cases involving foreign elements- remains unsolved. The course approaches decisively the matter thanks to the powerful weapons provided by European private international law. The ECJ case law regarding the "harmful event" ground of jurisdiction, -now located in Article 7.2 of the Brussels I-a regulation-, and its evolution in the case law trilogy Mines de potasse, Shevill and eDate are analyzed. The creation by the ECJ of a specific ground of jurisdiction for damage to personality rights on the Internet based on the place where the bulk of the damage takes place, which corresponds, in general, to the Member State of the habitual residence of the victim, is considered as positive. Not only is this perspective practical, but also efficient from an economic point of view when it comes to determining the place of the damage for the purposes of jurisdiction. Yet again, it is Accessorium sequitur principale, the good old Roma Law adage. The victim can claim for the damages suffered worldwide before just one single court, the court of the Member State where he has his habitual residence. This can be called an efficient jurisdiction. 
With regard to the Law applicable to non-contractual liability arising from the violation of personality rights on the Internet, the course brings to light deficiencies and weaknesses of the current regulation. Rome II Regulation does not apply to these issues. Each member State has its own national conflict of laws rules in this sector. In Spain, Art. 10.9 CC applies: a rudimentary legal provision that affords many problems and few solutions. Prof. CARRASCOSA's course follows an economic approach with satisfactory results. The best connecting factor is considered, again, the habitual residence of the victim, provided that the main damage to the personality rights has taken place in that country. This is the most predictable law for victim and offender alike and it is the Law that entails the lowest costs for the parties. Finally, the course dwells on cases of so-called "cyberlibel tourism". This happens when the claimant starts legal actions for defamation on the Internet before the courts of a specific country just because the online defamatory content is accessible from that country. Once the judgment is rendered, the victim asks for its recognition in the country where he resides.

In short, this is a text full of coloured perspectives: no solution is accepted without weighing all its strengths and weaknesses. A must have, an upmarket page-turner. Both the bibliography and comparative law apparatus used are indeed exhaustive. It is a well written work that shuns complicated and obscure expressions; a work full of light and nuances, in which the private international law lover will discover delightful historical aspects, current technical issues related to the Internet, and an interpretation of private international law as a branch of the legal system that seeks an efficient implementation of human rights. The architecture of the world has changed, Prof. $\mathrm{CA}_{\mathrm{A}}$ RRASCOSA tells us, but at the centre of the world one can still see the human being, armed with a protective shield and a shining armour called "Private international law". 